Numerous fossils, rare mountain plants, case of insects, specimens of photozincography, cotton in its various stages of manufacture, and foreign curiosities and works of art were also exhibited by gentlemen who were interested in the association, as well as a number of drawings and designs, some by pupils of the York School of Art, and some handsome literary work, not only as regarded their intrinsic merit, but as specimens of elaborate binding and typography. In the course of the evening Dr. Proctor, of York, gave some very pleasing experiments with Ruhmkorff's coil in an adjoining room. He first of all explained the principle on which the coil and battery were constructed. The electric spark was then produced, and a number of experiments were given to show the beautiful vari-coloured optical effects produced by passing the electric current through different gases and various other chemical preparations. At the request of Dr. Christie, Dr. Richardson, of London, also gave a demonstration of the action of his painless cutting knife, which he has lately introduced into surgical practice. The knife consists of a rapidly revolving lancet cutting blade, in fact, a cutting wheel with an extremely sharp edge. The blade revolves at the rate of twenty-five revolutions per second, and when it is placed upon the skin it cuts right through the skin without conveying any sensation or consciousness of pain. Dr. Richardson exhibited this on his own arm, making a moderately free incision. He explained that he was particularly anxious to have it understood that the instrument was at present only intended for the smaller operations in surgery, and that he was desiring only at this moment to give to every surgeon a little pocket instrument, by means of which he could perform daily, without the danger of anesthetics, many small, but extremely painful, operations on the body. During the evening Messrs. Terry supplied tea, coffee, ices, and other refreshments, which were disposed of under the superintendence of $\mathbf{M r}$. Dolby; and everything was done to make the conversazione pleasurable to all. A number of choice plants were tastefully arranged in the ante-room. The company separated shortly before midnight.

\title{
CORRESPONDENCE.
}

\section{Letter from M. Brierre de Boismont.}

\section{(Translation.)}

MONSIEUR ET HONORÉ CONFRERE,

PARIs, July 12, 1869.

I have just read in the July number of the Journal of Mental Science, page 266, a passage which has much pained me. This is the beginning and the end of it : "One finds in history that it was in the time of Napoleon I. that Maisons de Santé first played an important part in the government as private state prisons . . . . Under the Bourbons, up to 1830, it was the turn of the Bonapartists to fill the Maisons de Santé ; under Louis Philippe, the Republicans, and the Legitimists were more or less shut up in them, and since the establishment of the second empire it has been towards the persecution of political writers in country newspapers, or of too free-thinking students that Maisons de Santé have been directed."

People may write what they like, but others can also reply, and that is what I intend to do, premising that I do not ask for any redress. For a long time past prisoners in France belonging to the richer classes used to ask, as a favour, to be transferred from the prisons to the Maisons de Santé. Under Napoleon the 1st the government, anxious to have some guarantee for the safety of its prisoners, only granted leave of removal to those houses which were so arranged as to prevent escape; but a condition of great importance was attached to the transfer of these prisoners, not as insane, but simply as persons detained. The director signed an engagement on his personal responsibility to take every precaution to prevent the escape of the prisoners, and you will easily see to what those who signed these engagements exposed themselves. The private house of which I had the charge in 1848 , had received patients in 1769 , as proved by the admission of a 
lunatic on Aug. 20th, 1769. This house, one of the most ancient in Paris, for Louis XIV. came to it in 1659 , on his return from St. Jean de Luz, as is also proved by an inscription which freed it from the gabelle dues, was probably one of the first selected to receive those prisoners who were fortunate enough to be removed from their gaolers. It was, indeed, to this house (at that time there was no law to prevent such houses taking any but insane ; that law was not made till 1838) that MM. Armaud and Jules, and the Prince de Polignac, not in 1802, but on June 22rd, 1810, were transferred.

This is a literal copy of the extract from the register:-

"By order of his Excellency, the Minister of the General Police, MM. Armaud and Jules, coming from the fortress of Vincennes, and conducted by Sieur Pagne, officier de paix, have been entrusted to my care till further orders from the Minister.-(Signed) Dubuisson, nephew."

Their discharge took place on July 12th, 1812, having been ordered by the minister. These gentlemen had been eight years in the prison of Vincennes and only two years in the Maison de Santé, where they were treated as detained persons, and not as insane.

I will give you an instance of the risk to which the reception of these inmates exposed the proprietor of the house.

The other person referred to in the passage in the Mental Science, General Mallet, was placed in the house under the following order: "M. Mallet, Claude François, Ex-General, coming from St. Pelagie (another prison), and brought by Sieur Lafitte, officier de paix, will be given into the charge of M. Dubuisson, nephew, director of the house, to be detained there, by order of the Councillor of State, Prefect of Police, Count of the Empire, dated the 13th January, 1810."

Some time before his escape, on the 22nd Oct., 1812, General Mallet, having made an attempt at escape, was retaken by $M$. Dubuisson, and the latter informed the Prefect of Police immediately, who paid very little attention to it. When the general, for a moment the master of Paris, had been taken prisoner, a company of infantry surrounded the house and arrested M. Dubuisson. When he appeared before the Duc de Rovigo, minister of police, the latter addressed him in these terms: "You have let the chief of the conspiracy escape, you are going to be tried with the others, and you will accompany them to the Place de Grenelle "-(about 25 were shot). M. Dubuisson told the minister that he had given the administration warning. His report was found up and he was set at liberty, but the impression made on his mind was such that he died insane, not long after in his own establishment.

You see, then, sir and honoured confrère, that these detained persons were sent to our houses as prisoners, for whom the directors were held responsible, and that this responsibility might involve very disagreeable consequences. It was an obligation forced upon them, and a favour ardently sought for by the prisoners. Since the law of 1838, the Maisons de Santé, being confined entirely to the insane, have no longer taken political prisoners, unless they had a special quarter, which is very rare, and when the director accepts such a charge he has to sign an engagement, binding him very stringently to provide against escapes.

Such a proposition was made to me some 20 years ago, but I refused it, as only taking lunatics. The individuals included in this category succeeded, with great influence, and still only a few in number, in getting admission into Maisons de Santé, which did not take lunatics.

I have followed up with great care the complaints made by newspaper writers as to arbitrary detentions, but I do not know of a single decision which has gone against the director of any asylum, public or private, for this cause. The Chamber of Deputies contains energetic opponents of the powers that be, who have not hesitated to say openly before the house, that the 2nd of December was a crime, and they would not have shrunk from bringing before public opinion the detention of a man for political reasons in a Maison de Santé. Lastly, three months' ago, in the assembly of Legislation comparé, composed of magistrates and lawyers, I begged to be informed of a single conviction of an asylum physician for such a thing, and no one could give an instance. 
Allow me now, sir, to remind you of the following lines, which occur in p. 301 of the same number of the Journal of Mental Science: "Galileo was morally a representative of his age, deficient in native firmness of character, as Scarpa has clearly shown, conceited but without personal dignity, he combated the malignant baseness of his enemies by subterfuge and pusillanimity . . . What was persecuted in Galileo, what was attempted to be stifled with terror, was not so much an astronomical hypothesis as the liberty of scientifio investigation; and what Galileo has especially upheld, when defending Copernicus and himself, is the right of science to develope itself in all the plenitude of its independence."

The medical man who, in all his writings, has upheld the unalienable rights of humanity and science, would rather a thousand times have closed his house than commit an act for which his conscience would reproach him.

Accept, sir, and honoured confrère, the assurance of my distinguished sentiments.

\section{A. Brierre de Boismont.}

We gladly pullish M. Brierre de Boismont's explanatory letter. The facts he refutes were quoted, as will be seen by reference to the "Occasional Note" in question, from a curious paper in the "Cornhill Magazine" for Fune. We must, however, adhere to our statement (which M. Brierre de Boismont leaves unnoticed, except by implication) that we have been informed on undoulted authority, such as M. Brierre de Boismont could not question, that the second Empire-as did the first, according to the writer in the "Cornhill"-frequently sends noisy political adversaries for temporary treatment in the Bicêtre. Difficulties have arisen, as he can easily inform himself, with the physicians of that asylum and the Minister of the Interior on this very question.

\section{VITAL AND COSMICAL FORCE.}

\section{To the Editors of the Journal of Mental Science.}

\section{Gentlemen,}

I noticed in your issue for July a short but clever critique of a recent paper of mine on the above subject, in which I attempt to show that there is no occult principle present in vital phenomena, but that the problem of sensation and self-motion is one entirely for natural science and rational inquiry.

Aware, as you are, that I have advocated this view for at least twenty years past, I hope that however much you may distrust my data and inferences, you will yet, for the sake of fair play and an open field to consistent scientific convictions, however unpopular, and opposed alike to the current vulgar superstitions of civilised Europe and the pedantry of savans and systems, not shrink from the responsibility of giving insertion to the following brief elucidatory remarks from my own hand in the forthcoming number of the Journal of Mental Science.

My argument is that vital action is electrical-using the term electricity as one of the modes of physical force-the correlative of light, heat, and attraction. The rationale of this hypothesis becomes quite apparent if we assume (the grounds for which are detailed further on) that oxygen gas-the element alike essential for respiration and combustion-can exist in the "capillaries," where the ultimate processes of vitality are effected, as an imponderable ether. By this assumption we get rid entirely of dualism in the seemingly double, but really single, kingdom of animate and inanimate creation.

This postulate seems self evident. If oxygen gas (fire air or vital air) be capillary force, which is merely another name for animal function, the entire phenomena of the cosmos, including sensation and voluntary motion, are seen to have for their factor the self-same universal principle, only under different conditions of activity. In other words the distinction between the personal, indivi- 